\title{
SISTEM EVALUASI MODEL GREEN SUPPLY CHAIN MANAGEMENT UNTUK MENINGKATKAN KINERJA KEUANGAN UMKM TEPUNG TAPIOKA KABUPATEN PATI
}

\author{
Daniel Alfa Puryono \\ Program Studi Sistem Informasi \\ STIMIK AKI \\ Email: danielsempurna@gmail.com \\ Listiarini Edy Sudiati \\ Program Studi Sistem Informasi \\ STIMIK AKI \\ Email: listiarini@gmail.com
}

\begin{abstract}
ABSTRAK
Sistem evaluasi yang digunakan untuk mengatasi permasalahan pada studi kasus ini mengunakan model Green Supply Chain Management (GSCM). Model GSCM adalah solusi yang dapat menilai, mengevalusi dan mengembangkan masalah industri, lingkungan sosial dan ekomoni. GSCM digunakan untuk hubungan timbal balik antar praktik rantai pasok yang ramah linkungan. Sedangkan metode Analytical Hierarchy Process (AHP) untuk pengambilan keputusan agar lebih terukur dan konsisten. Selain itu juga mengunakan metode analisis Du pont untuk menilai dan mengevaluasi tingkat kinerja keuangan pada Usaha Mikro Kecil dan Menegah (UMKM). Kombinasi dari metode yang digunakan dapat membantu para pengambil keputusan serta dapat mengevaluasi progam yang komplek menjadi lebih efesien, sehingga akan tercapai pembangunan yang berkesinambungan. Hasil penelitan ini juga dapat memberikan petunjuk dan pedoman bagi para analisis dan pengambil keputusan, serta dapat menjadi masukan yang berdampak pada peningkatan kinerja dan keuangan UMKM tepung tapioka. Studi lapangan, penyebaran kuesioner dan wawancara dilakukan untuk menggambarkan metodologi yang digunakan.
\end{abstract}

Kata kunci: GSCM; AHP; UMKM; kinerja keuangan.

\begin{abstract}
The evaluation system used to overcome the problems in this case study uses the Green Supply Chain Management (GSCM) model. The GSCM model is a solution that can assess, evaluate and develop industrial problems, social and economic environments. GSCM is used for reciprocal relationships between environmentally friendly supply chain practices. While the Analytical Hierarchy Process (AHP) method for decision-making is more measurable and consistent. Besides that, it also uses the DuPont analysis method to assess and evaluate the level of financial performance in Micro, Small and Medium Enterprises (MSMEs). The combination of the methods used can help decision makers and be able to evaluate complex programs to be more efficient, so that sustainable development will be achieved. The results of this research can also provide guidance and guidelines for the analysis and decision makers, and can be an input that has an impact on improving the performance and finances of SME tapioca flour. Field studies, questionnaires and interviews were conducted to describe the methodology used.
\end{abstract}

Keywords: GSCM; AHP; UMKM; financial performance.

\section{PENDAHULUAN}

Pencemaran akan lingkungan sudah menjadi kekhawatiran yang berkembang di seluruh dunia. Peningkatan emisi rumah kaca memiliki efek buruk pada lingkungan yang dapat mempengarui bumi ini [1]. Pemanasan global serta populasi manusia yang terus meningkat membuat konsumsi sumber daya alam juga meningkat oleh karena itu isu-isu lingkungan perlu mendapat perhatian serius. Salah satu penyebab degradasi lingkungan adalah meningkatnya industrialisasi diseluruh dunia. Pada tahun 2016 telah terjadi peningkatan pencemaran yang signifikan. Bahkan dari beberapa media online, Indonesia menduduki peringkat nomer tiga di dunia untuk tingkat polusi udara. Hal ini memiliki efek buruk pada 
kondisi iklim di negara ini. Di sisi lain Indonesia merupakan negara berkembang dan memajukan industri adalah salah satu strategi untuk mengatasi masalah pertumbuhan ekonomi.

Peningkatan pencemaran lingkungan adalah salah satu topik paling penting di dunia saat ini. Industrialisasi telah banyak menyebabkan kerusakan pada sistem kehidupan manusia dan lingkungan alam. Proses produksi tepung tapioka mewakili sumber pencemaran lingkungan yang perlu mendapatkan banyak perhatian. Karena kegiatan industri ini dapat menimbulkan ancaman yang signifikan terhadap lingkungan. Terkait dengan masalah diatas teknik dan pendekatan telah banyak dikembangkan. Rantai pasok ramah lingkungan adalah salah satu hal penting dan menjadi stategis untuk proses produksi dalam era industri sekarang ini. Karena pendekatan ini dapat mengatasi permasalahan lingkungan yang serius akibat dampak yang ditimbulkan dari proses industri. Para pemilik usaha juga akan mendapat gambaran dan wawasan baru mengani pentingnya industri ramah lingkungan dan berkelanjutan.

Tepung tapioka merupakan produk unggulan di Kabupaten Pati. Maka penggelolan dan peningkatan kwaliatas produksinya agar dapat bersaing dengan yang lain menjadi penting. Peningkatan produk dengan tetap menjaga lingkungan serta mengurangi limbah dan polusi merupakan strategi untuk mencapai pembangunan yang berkesinambungan bagi UMKM dan industri saat ini. Menurut Camat Margoyoso pada tahun 2016 total UMKM tepung tapioka di Kecamatan Margoyoso Pati ada 530 baik dalam sekala industri maupun rumah tanggan. Luas lahan di Kabupaten Pati yang ditanami ketela pohon sebagai bahan utama pembuat tepung tapioka sekitar 18.259 hektar. Tingkat produktifitas perhektar $217,70 \mathrm{kwintal}$ jadi kurang lebih total produksi ketela yang dihasilkan mencapai 397,498 ton.

Namun belum terselesainya permasalahan tentang pencemaran lingkungan disekitar lokasi UMKM tepung tapioka membuat keprihatinan tersendiri khususnya pemerintah daerah di Kecamatan Margoyoso Pati. Permasalahan tersebut dikarenakan dampak dari limbah cair yang langsung dibuang ke lingkungan sekitar maupun sungai, tanpa mengalami proses pengolahan ataupun penyaringan terlebih dahulu. Sedangkan limbah industri ini mudah membusuk dan berbau sangat menyengat. Sudah ada 5 sungai yang tercemar yaitu sungai cebolek, bango, pangkalan, pasokan dan suwatu. Jadi kalau hal ini dibiarkan terus menerus akan berdampak terhadap pencemaran lingkungan yang lain. Seperti pada persawaan, tambak ikan dan udang di Kecamatan tersebut. Sehingga imbasnya para petani akan gagal panen. Hal ini akan memicu konflik sosial ekonomi diantara masyarakat sekitar. Oleh sebab itu perlu tanggung jawab dari semua pihak, termasuk pemilik usaha serta konsumen dalam upaya melestarikan lingkungan. Permasalahan tersebut yang mendorong diusulkanya sistem evaluasi model rantai pasok ramah lingkungan untuk mengurangi masalah lingkungan serta meningkatkan kinerja keuangan dari proses produksi tepung tapioka di Kabupaten Pati. Sehingga akan tercapai pembangunan yang berkesinambungan.

Konsep dari manajemen rantai pasok ramah lingkungan atau GSCM pada dasarnya bertujuan untuk mengubungkan antara pengelolaan rantai pasok dengan faktor-faktor yang bisa mempengarui proses terhadap lingkungan secara efektif dan efesien [2]. Sudah banyak industri di seluruh dunia yang menerapkan teknik GSCM untuk mengatasi masalah lingkungan. Bahkan disebagian besar negara maju GSCM merupakan konsep yang sudah cukup terkenal. Hanya memang di Indoenesia konsep GSCM masih relatif baru dan penerapanya masih kontradiktif. Karena faktanya disatu sisi tekanan sosial memaksa industri harus menerapkan praktik-praktik ramah lingkungan. Karena pencemaran lingkungan telah menjadi permasalahan tersendiri untuk masyarakat di Indoensia. Tetapi disisi yang lain, ada kekawatiran tentang bagaimana faktor-faktor ini akan mempengaruhi kinerja atau keuntungan sebuah industri.

Padahal dengan menerapkan GSCM secara benar mempunyai banyak manfaat penting dalam ekonomi. Karena penerapan GSCM bisa mengurangi biaya langsung, biaya keuangan dari industri termasuk mengurangi denda dari lingkungan, mengurangi biaya konsumsi energi, biaya pembelian bahan dan biaya fasilitas [3]. Konsep rantai pasok ramah lingkungan dapat membantu untuk mengevaluasi dampak lingkungan secara global dan sistemik [4]. Jadi GSCM merupakan pendekatan yang terintegrasi serta dapat membantu UMKM untuk mengembangkan strategi yang baik serta menanbah keuntungan, laba dan pencapaian tujuan UMKM dalam hal efesiensi dan perbaikan lingkungan [3], [5].

Banyak peneliti telah mengunakan metode untuk menyelidiki faktor ramah lingkungan dengan cara mengukur kriteria untuk penerapan GSCM seperti mengunakan metode AHP [6], AHP-TOPSIS [7]. Sedangkan penelitian ini mengembangkan dan mengkombinasikan beberapa kriteria dalam pengambilan keputusan. Yaitu dengan mengunakan model GSCM untuk evaluasi hubungan timbal balik antar praktik rantai pasok. Serta mengunakan metode Analytical Hyerarki Proses (AHP) untuk pengambilan keputusan agar lebih terukur dan efesien. Selain itu juga mengunakan analisis Du pont untuk menilai dan mengevaluasi tingkat kinerja keuangan. Karena kombinasi dari metode yang digunakan dapat membantu para pengambil keputusan serta dapat mengevaluasi progam yang komplek menjadi lebih efesien.

Pengenalan teknologi informasi serta globalisasi ekonomi dan e-bisnis menimbulkan tantangan baru bagi semua organisasi terutama untuk UMKM. Karena masih banyak UMKM yang kurang menyadari 
perlunya adopsi sistem, bahkan belum siap untuk menerapkan sistem informasi bisnis yang berbasis ramah lingkungan. Sistem informasi ramah lingkungan adalah program aplikasi atau alat yang mampu menyesuaikan dengan perubahan yang ada. Maka dari itu sistem informasi harus melibatkan semua komponen mulai dari proses pembuatan, basis pengetahuan sampai pada tahap evaluasi. Sedangkan dari segi pengguna sistem informasi itu sendiri harus mampu mengoperasikan, mengendalikan serta menyesuaikan dengan perubahan lingkungan yang terus mengalami perubahaan. Untuk itu sistem harus menyediakan pembaruan secara konsisten dan berkelanjutan agar dapat mengimbangi perubahan lingkungan yang terus mengalami perubahan sehingga memudahkan pengguna [8].

Jadi penting untuk mengatasi permasalahan di atas, dengan mengunakan sistem evaluasi GSCM agar kekawatiran tentang penerapan dan pengembangkan UMKM berkelanjutan dari sektor industri bisa diidentifikasi, dikembangkan serat dilakukan perbaikan-perbaikan. Karena menurut beberapa hasil penelitian dengan mengatasi aspek lingkungan dapat membantu dalam mengenali peluang baru yang mengarah ke keunggulan kompetitif, melalui kebijakan seperti daur ulang limbah, penggunaan kembali bahan baku, proses produksi yang bersih, dan pengelolaan sampah sehingga dapat membantu dalam mencapai tujuan lingkungan [9]. Sesunguhnya sudah banyak dibuktikan bahwa GSCM dapat menjadi elemen penting dalam meningkatkan kinerja organisasi serta menambah nilai manfaat untuk persaingan pasar [5]. Bahkan bisa untuk meningkatkan kinerja keuangan perusahaan.

\section{METODOLOGI PENELITIAN}

\subsection{Teknik Pengumpulan Data}

Teknik untuk mengumpulkan data dilakukan dengan membagikan kuesioner yang berisi tentang tingkat kepentingan kinerja rantai pasok. Kuesioner ini diberikan kepada 15 pemilik industri tepung tapioka yang mengerti tentang proses rantai pasok, permasalahan lingkungan dan kinerja keuangan. Selain itu untuk mendapatkan tambahan data keuangan juga ditanyakan model laporan keuangan mereka secara langsung kepada para pelaku UMKM, melalui teknik wawancara dengan memasukan salinan laporan keuangan mereka per periode secara umum.

\subsection{Peran Kombinasi Metode yang Digunakan}

Proses evalusi dan penilaian GSCM untuk kinerja keuangan pada UMKM dilakukan dengan cara responden mengisi kuesioner dan memasukan hasil laporan keuangan per periode, kemudian hasil tersebut dianalisa dan didapatkan kesimpulan melalui sistem aplikasi berbasis web. Dalam aplikasi tersebut ada beberapa kombinasi metode yang digunakan yaitu dengan pemilihan KPI mulai dari proses rantai pasok, kinerja dari rantai pasok serta kinerja keuangan mengunakan kerangka ramah lingkungan yang ada didalam model GSCM. Kemudian dilanjutkan dengan mengunakan metode AHP yaitu dengan cara menyusun hirarki dari tujuan UMKM, melakukan pembobotan kriteria dan alternatif berdasarkan pendapat dari para ahli atau pemilik usaha, penentuan prioritas, mengitung konsistensi dan indek konsistensi maupun rasio konsistensinya agar pendapat para ahli dapat diukur dan dipertangungjawabkan validasinya [5]. Formula dalam metode AHP untuk mengitung indek konsistensi sebagai berikut :

$C I=\frac{\lambda_{m a k s}-n}{n-1}$

$\mathrm{n}$ merupakan banyaknya elemen, sedangkan $\lambda_{\text {maks }}$ adalah nilai rata-rata yang dihitung sebelumnya. Jika hasil perhitungan didapat $\mathrm{CI}=0$ maka pengambil keputusan dinyatakan konsisten. Dasar yang digunakan untuk menentukan konsisten atau inkonsistensi hasil adalah dari tabel indeks konsistensi. Sedangkan formula yang digunakan untuk menghitung rasio konsistensi (CR) sebagai berikut :

$C R=\frac{C I}{I R}$

Keterangan :

$\mathrm{CR}=$ Rasio konsistensi

$\mathrm{CI}=$ Indeks konsistensi

IR = Indeks Random

Sedangkan analisis Du-pont digunakan untuk mengukur rasio keuangan. Yaitu dengan cara mencari indek Return On Assets (ROA) guna mendapatkan tingkat efesiensi kinerja keuangan dengan mengunakan rumus sebagai berikut : 
Return on Assets $=\frac{\text { Laba bersih setelah pajak } \times 100 \%}{\text { Total Aktiva }}$

Sedangkan untuk menghubungkan kinerja rantai pasok terhadap kinerja keuangan, mengunakan Economic Value Add (EVA). Karena pengukuran kinerja keuangan dengan pendekatan ini akan menghasilkan hubungan antar indikator kinerja rantai pasok dengan indikator kinerja keuangan. Sehingga tercapai hasil evaluasi untuk mengetahui profitabilitas dan efesiensi operasonal UMKM yang ramah lingkungan. Penggunaan rumus EVA tersebut dapat dinyatakan sebagai berikut:

$$
\text { EVA }=\text { NOPAT }- \text { Capital Charges }
$$

Keterangan :

NOPAT $=$ Net Operating After Tax (Laba bersih setelah pajak)

Capital Charges $=$ Modal Investasi atau Biaya Modal

\subsection{Analisa Sistem Informasi}

Analisis sangat penting untuk keberhasilan suatu proyek pengembangan sistem. Metodologi berikut digunakan untuk mengetahui persyaratan sistem dari perspektif pengguna :

a) Tinjauan dokumen: yaitu dengan cara mencari tau proses bahan baku, proses produksi, manajemen, penjualan, pengiriman dan pembuangan limbah. Cara ini bertujuan untuk menentukan parameter kunci dalam pengembangan sistem.

b) Wawancara: Wawancara secara langsung dilakukan untuk memahami persyaratan penting dalam rangka mengetahui kebutuhan di masa depan. Orang yang diwawancarai juga diminta untuk memberikan pertangung jawaban pertanyaan tentang alur kerja, input-output, tugas dan pemahaman mereka tentang informasi rantai pasok tepung tapioka. Perangkat teknologi informasi, aplikasi yang digunakan maupun limbah yang dihasilkan apakah dimanfaatkan atau dibuang secara terfokus.

\subsection{Desain Kerangka Sistem Informasi}

Sistem informasi yang dirancang memiliki lapisan antarmuka bagi pengguna, lapisan bisnis dan lapisan layanan data. Masing-masing lapisan sistem dimodifikasi dan disempurnakan. Lapisan bisnis merupakan inti dari sistem aplikasi yang juga terkait dengan lapisan layanan data dan lapisan antarmuka bagi pengguna. Selanjutnya permintaan layanan yang dihasilkan oleh pengguna akhir akan diproses pada lapisan logika bisnis. Tempat data pengguna diproses dan dikonfigurasi sebagai parameter ke layanan bisnis dan lapisan antarmuka. Lapisan antarmuka pengguna adalah bagian dari interaksi antara manusia dan komputer yang menunjukkan data pengguna melalui visualisasi antarmuka sistem, manajemen data dan pengaturan [10]. Kerangka kerja sistem informasi tersebut seperti pada gambar 1 berikut ini.

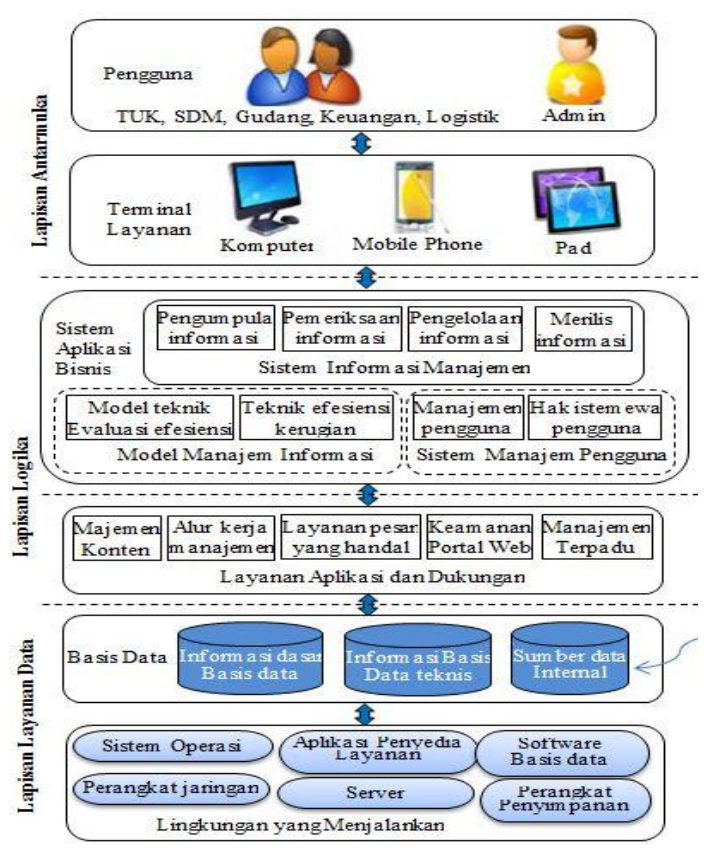

Gambar 1. Kerangka Kerja Sistem Informasi [10] 


\section{HASIL DAN PEMBAHASAN}

\subsection{Rantai Pasok UMKM Tepung Tapioka}

Rantai pasok diidentifikasi terdiri dari produsen, pemasok, transport, gudang, pengecer dan pelangan yang secara langsung atau tidak langsung berkontibusi untuk permintaan pelangan [5]. Mengelola masalah rantai pasok ini akan membantu mengurai masalah lingkungan yang terkait dengan produksi tepung tapioka. Sebagai contoh rusaknya habitat sungai, pertanian dan tambak di sekitar industri karena air dan udara yang sudah terkontaminasi limbah industri tepung tapioka. Beberapa media online berpendapat bahwa industri tepung tapioka dikenal memiliki reputasi lingkungan yang buruk. Tetapi mau tidak mua karena tekanan sosial masyarakat, serta peraturan-peraturan untuk meningkatkan industri agar lebih kompetitif dan ramah terhadap lingkuangan, maka industri harus mempunyai solusi kegiatan yang terfokus pada rantai pasok ramah lingkungan, minimal pada kegiatan internal industri itu sendiri.

Kegiatan rantai pasok dalam industri tepung tapioka terdiri dari pencatatan kegiatan transaksi seharihari serta menjaga hubungan baik dengan pemasok dan pemerintah. Sedangkan kegiatan manajemen sumber daya manusia dalam industri ini terdiri dari pemilihan pekerja serta berpartisipasi dalam pelatihan yang diselenggarakan oleh klaster, forum maupun pemerintah daerah. Kondisi saat ini sebagian besar UMKM tepung tapioka masih menggunakan peralatan tradisional dan belum memanfaatkan peralatan terbaru atau teknologi. Sedangkan untuk proses logistik dimulai dari pemilihan bahan baku yang digunakan untuk proses produksi tepung tapioka mengunakan ketela pohon. Kemudian dilanjutkan dengan proses penerimaan, menyimpan, mengelola dan mengendalikan kegiatan terhadap bahan tepung tapioka serta cara pembayaranya. Sedangkan kegiatan operasi terdiri dari kegiatan untuk mengkonversi bahan baku menjadi produk jadi. Dalam industri tepung tapioka, untuk mengkonversi ketela menjadi tepung ada beberapa proses yang digunakan, mulai dari pencucian, pengilingan, penyaringan, pengeringan sampai proses pengepakan dan penjualan produk tepung.

\subsection{Evaluasi Berbasis Web}

Pada era sekarang ini pengendalian pencemaran harus sudah melibatkan serta mengunakan perangkat teknologi informasi agar secara efektif dapat melindungi lingkungan, mengintegrasikan operasional pemasok sampai dengan pengecer dan menjadi pembelajaran bagi para pemangku kepentingan. Industri harus berkolaborasi dalam hal perencanaan, evaluasi, peramalah dan layanan yang lain untuk dapat mengurangi resiko bagi lingkungan dalam jaringan rantai pasok yang berkelanjutan. Sistem evaluasi yang diusulkan menggunakan platform survei dan input laporan berbasis web untuk mengumpulkan pendapat dari pengguna tentang rantai pasok yang ramah lingkungan. Survei berbasis web adalah cara yang mudah dan murah. Serta dapat membantu sistem evaluasi untuk menjangkau sejumlah besar pengguna dalam waktu singkat dan mengatasi masalah yang terkait dengan jarak geografis maupun sumber daya.

Memang survei berbasis web memiliki kelemahan tentang tingkat kepercaya dari responden yang mengisi kuesioner. Kemungkinan dalam mengisi kuesioner ada ketidak jujuran. Seperti input yang berulang dan tidak konsistennya data, namun dengan mengunakan langkah-langkah yang ada dalam kombinasi metode yang digunakan terutama AHP nilai inkonsistensi bisa diselesaikan. Sehingga dapat mencegah inkonsistensi yang disebabkan oleh input data atau kesalahan penginputan. Data prapemprosesan atau validasi juga dapat digunakan untuk menghilangkan data yang tidak dapat dipercaya dari survei. Ketika pengguna tidak memiliki pengalaman yang cukup untuk proses penilaian dan evaluasi. Metode AHP adalah sebuah pendakatan yang membantu mengorganisir dan menganalisa masalah yang komplek. Karena maslah-masalah tersebut disederhanakan dalam bentuk struktur hierarkis yang terdiri dari berbagai tingkatan tertentu, seperti tujuan, kriteria dan sub kriteria.

\subsection{Hasil Sistem Evaluasi}

Setelah pengguna aplikasi login kedalam sistem evaluasi, pengguna bisa melakukan pemilihan periode dan tahun yang akan di evaluasi. Mereka akan diminta masuk ke dalam menu pengisian kuesioner, namun jika terjadi kesalahan atau belum sesuai dengan pilihanya pengguna dapat melakukan edit kuesioner.

Dalam sistem ini pengguna juga bisa melihat proses uji analisi data hasil kuesioner. Baik pada proses pengadaan, produksi, pengiriman, pengembalian maupun kinerja keuangan. Melalui proses analisis data tersebut akan diketahui para kepala bagian dalam mengisi kuesioner sudah sesuai aturan atau belum. Bahkan sudah konsisten terhadap jawabanya atau dalam mengisi hanya asal asalan saja. Sebab akan diketahui jika rasio konsistensi para responden dalam mengisi kuesioner masih di bawah batas indek 
konsistensi maka dapat dikatakan responden konsisten terhadap jawabannya. Namun jika melebihi dari angka yang sudah ditetapkan tersebut berarti para responden dalam mengisi kuesioner tidak konsisten. Maka responden wajib untuk mengisi ulang kuesioner tersebut. Sampai sistem menyatakan bahwa responden konsisten terhadap jawabanya. Sebagai contoh hasil uji konsitensi pada proses pengembalian seperti gambar 2 dibawah ini.

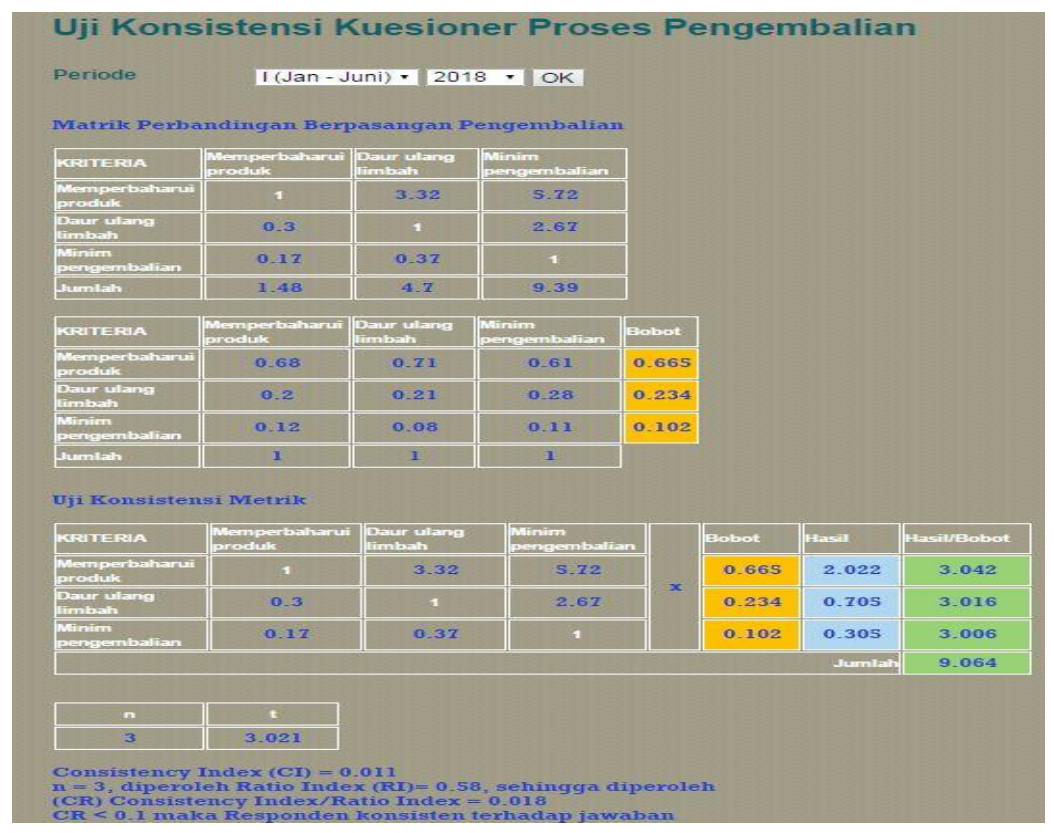

\section{Gambar 2. Uji Konsistensi Kuesioner}

Pengunaan juga dapat melihat tampilan grafik maupun rangking dari masing-masing kinerja seperti pengadaan, produksi, pengiriman, pengembalian dan semua alternatif kriteria rantai pasok ramah lingkungan yang ada di dalamnya. Hasil perhitungan dari kombinasi metode yang digunakan untuk kinerja rantai pasok seperti pada gambar 3 .

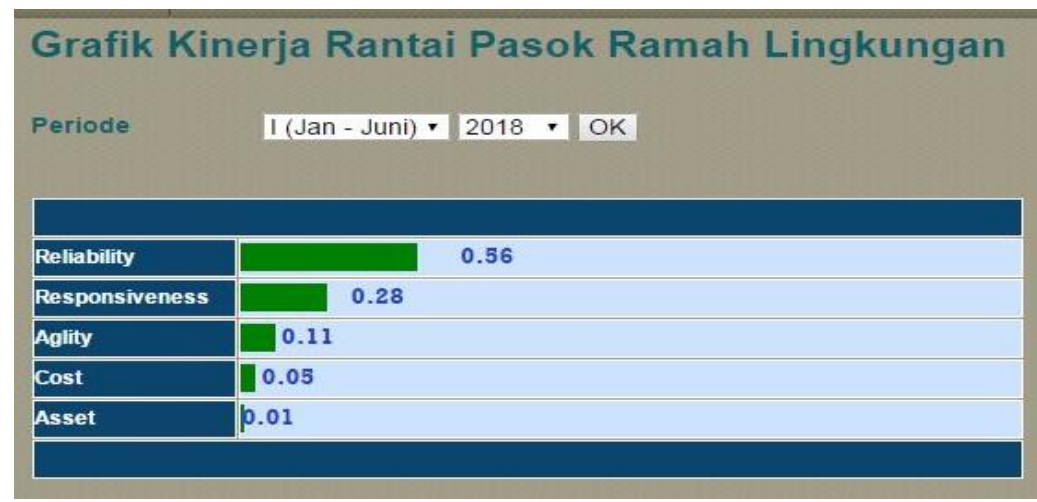

\section{Gambar 3. Rangking Kinerja Rantai Pasok Ramah Lingkungan}

Selain itu pengguna juga bisa melihat dalam menu bentuk grafik informasi maupun prosentasi, prioritas dari kinerja keuangan dan kondisi keuangan pada UMKM. Contoh seperti terlihat pada gambar 4. Sehingga laporan evaluasi ini bisa dijadikan aset dan bahan atau sumber informasi secara berkelanjutan untuk mengelola UMKM agar lebih baik lagi kedepanya. Sampai tercapai tujuan dari kinerja UMKM. 


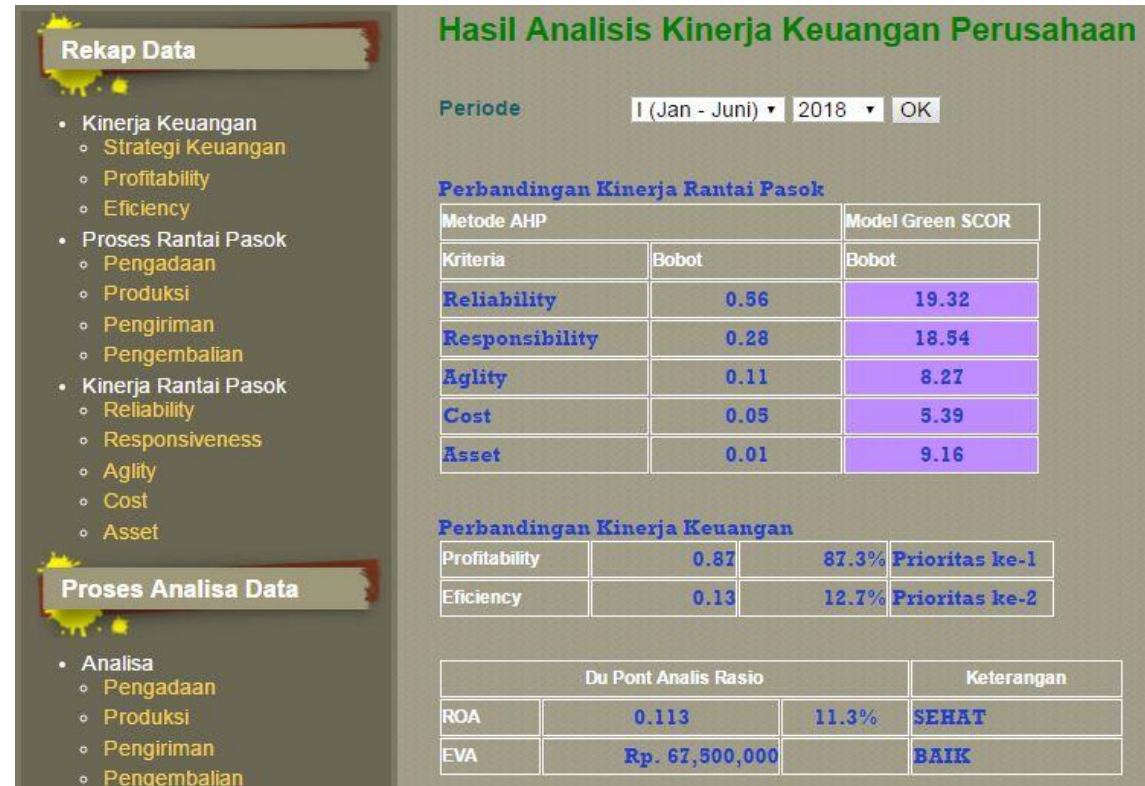

Gambar 4. Laporan Kinerja Keuangan UMKM

\section{KESIMPULAN}

Tujuan sebagian besar UMKM di negara berkembang seperti Indonesia adalah untuk memperbaiki kondisi ekonomi dan menghindari resiko ekonomi mereka. Namun karena kondisi saat ini dan kelestarian lingkungan telah menjadi aspek penting untuk dipertimbangkan. Oleh karena itu industri tepung tapioka harus berusaha menerapkan dan memastikan peningkatan perekonomi tanpa harus mengabaikan aspek lingkungan. Sistem evaluasi kegiatan rantai pasok yang ramah lingkungan adalah satu cara untuk memastikan bahwa proses peningkatan kinerja keuangan dan faktor lingkungan dapat terverifikasi dengan akurat dan tersistem.

Hasil penelitian ini menunjukkan bahwa melalui analisis dan sistem evaluasi yang dilakukan pada UMKM membuat praktek GSCM dapat mempengaruhi kinerja organisasi dan dapat meningkatkan kinerja keuangan sebesar $11,3 \%$. Selain itu juga ditemukan dengan menerapkan praktik GSCM dapat mengurangi pencemaran, polusi lingkungan dan biaya operasional dalam industri. Sedangkan berdasakan hasil sistem GSCM dapat mengevaluasi dampak sosial ekonomi, kesehatan, keselamatan pelangan dan karyawan, peningkatan kualitas produk dan jasa yang ramah lingkungan dengan biaya yang relatif rendah, produksi aman dan sehat dari hulu sampai ke hilir, mengurangi emisi karbon per kuartal, meningkatnya prosentase daur lurang dan meningkatan pendapatan setiap tahun. Oleh karena itu, tujuan melindungi lingkungan dan meningkatkan kepercayaan sosial ekonomi dapat dicapai dengan menerapkan sistem evaluasi praktik GSCM.

\section{UCAPAN TERIMA KASIH}

Terima kasih kepada Kemenristekdikti yang sudah membiayai penelitian ini. Juga pada UMKM tepung tapioka Kecamatan Margoyoso Pati atas data dan informasinya.

\section{DAFTAR PUSTAKA}

[1] S. Wang and M. Song, "Influences of reverse outsourcing on green technological progress from the perspective of a global supply chain," Science of the Total Environment, vol. 595, no. April, pp. 201-208, 2017.

[2] I. N. Mukharromah, P. Deoranto, S. A. Mustaniroh, and K. Sita, "Analisis pengukuran kinerja perusahaan dengan metode Green Supply Chain Management ( GSCM ) di unit bisnis teh hitam," Jurnal Penelitian Teh dan Kina, vol. 20, no. 1, pp. 48-58, 2017.

[3] S. Kusi-sarpong, J. Sarkis, and X. Wang, "Assessing green supply chain practices in the ghanaian mining industry: A framework and evaluation," Intern. Journal of Production Economics, vol. 181, pp. 325-341, 2016.

[4] R. Kumar, R. K. Singh, and R. Shankar, "Critical success factors for implementation of supply chain management in Indian small and medium enterprises and their impact on performance," IIMB 
Management Review, vol. xx, pp. 1-13, 2015.

[5] D. A. Puryono, F. Jie, and Mustafid, "Penerapan Green Supply Chain Management Untuk Peningkatan Kinerja Keuangan Perusahaan,” SINBIS, vol. 02, pp. 154-163, 2016.

[6] A. Diabat and K. Govindan, "An analysis of the drivers affecting the implementation of green supply chain management," Resources, Conservation and Recycling, vol. 55, pp. 659-667, 2011.

[7] X. Wang and H. Kai Chan, "A hierarchical fuzzy TOPSIS approach to assess improvement areas when implementing green supply chain initiatives," International Journal of Production Research, vol. 51, no. 10, pp. 3117-3130, 2013.

[8] Mustafid, "Sistem Informasi Untuk Supply Chain Berkelanjutan Berbasis Pengetahuan," SIMBIS, vol. 02, no. 5, pp. 109-118, 2015.

[9] U. Mumtaz, Y. Ali, and A. Petrillo, "A linear regression approach to evaluate the green supply chain management impact on industrial organizational performance," Science of the Total Environment, vol. 624, pp. 162-169, 2018.

[10] Y. Xu, B. Zhang, and L. Zhang, "A technical efficiency evaluation system for vegetable production in China," Information Processing in Agriculture, vol.5,no. 3, pp. 345-353, 2018. 